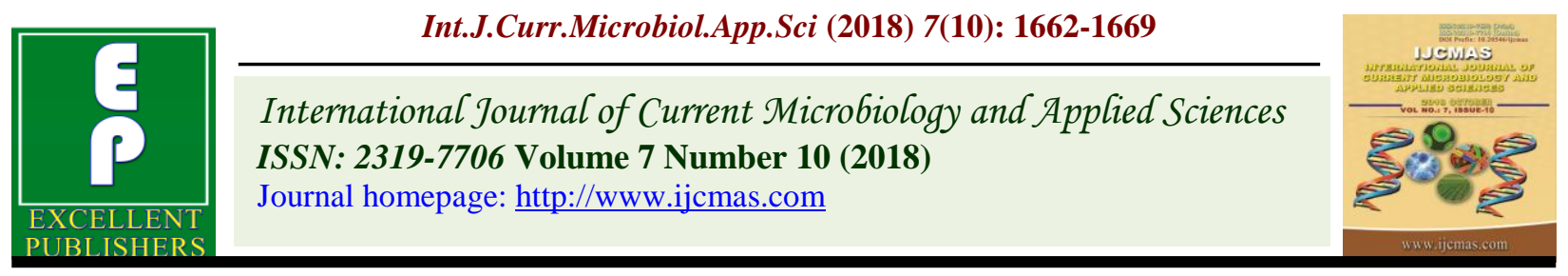

Original Research Article

https://doi.org/10.20546/ijcmas.2018.710.190

\title{
Studies on Induced Chemical Mutagenesis in Groundnut (Arachis hypogaea L.)
}

\author{
Mayur V. Jadhav*, Rahul K. Zote and Amol D. Sable \\ Department of Plant Biotechnology SDMVM's College of Agricultural Biotechnology, Georai \\ Tanda, Paithan Road, Aurangabad (M.S.) - 431001, India \\ *Corresponding author
}

\begin{tabular}{|l|}
\hline Ke y w o r d s \\
Groundnut, Sodium \\
azide, EMS, \\
Mutagenesis
\end{tabular}

\section{Introduction}

Commercially groundnut is the world's fourth most important source of edible oil and third most important source of vegetable protein, currently, groundnut is grown on nearly 25.20 million ha around the world with an annual production of 42.31 million tons of nuts-inshell. The major producers are China, India and the USA which together account for twothirds of the world output. Developing countries, account for 82 per cent of total groundnut area and 79 per cent of production of the world. Among the developing countries, production is mainly concentrated in Asia and Africa with Asia accounting for 51 per cent of global area and 60 per cent of production. India occupies 30 per cent of global area (6.6 
million ha) and contributes 22 per cent (5.9 million tons) of total groundnut production (FAO, 2014). Groundnuts are rich in essential nutrients (right table, USDA nutrient data, 2016). In a $100 \mathrm{~g}$ serving, peanuts provide 570 calories and are an excellent source (defined as more than $20 \%$ of the Daily Value,) of several B vitamins, Vitamin E, several Dietary minerals, such as manganese (95\% DV), magnesium (52\% DV) and phosphorus (48\% DV), and dietary fiber (right table). They also contain about $25 \mathrm{~g}$ protein per $100 \mathrm{~g}$ serving, a higher proportion than in many tree nuts. In Maharashtra various groundut variety where cultivated such as phule pragati (JL-24) It matures in 85-87 days. Its yield potential is 18-23 quintals per hectare. It has 72 percent shelling out turn and 50.7 percent oil. It is suitable for growing in Maharashtra, kopergoan-3: The crop matures in 100-105 days. It is suitable to grow under irrigated conditions in Maharashtra. It has 70 percent shelling out turn and 47 percent oil content. Its yield potential is about 13-18 quintals per hectare and A.K 12-24 it is a bunch variety recommended for cultivation in Vidarbh areas of Maharashtra, Orissa and Madhya Pradesh.

Seeds contain 48.5 percent oil. Shelling percentage is 75 . Yield potential is 12-15 quintals per hectare. Top growing district in Maharastra are Jalgoan, Solapur, Latur, etc. (ICAER, 2009). Mutation is a sudden heritable change in the genetic material of an organism. A number of physical and chemical mutagens have been used for induction of useful mutations in a number of crops. The approach of mutation breeding is to generate new genetic variability in a given crop species when there is little variation for a certain trait (Yadav et al., 2007). Among the known four types of mutations (genome, structural, extra nuclear and gene mutations), Ethyl methane sulphonate $\left(\mathrm{CH}_{3}-\mathrm{SO}_{2}-\mathrm{O}-\mathrm{C}_{2} \mathrm{H}_{5}\right)$ is a monofunctional alkylating agent and its mutagenic property was discovered by Loveless (1958) in
T2 bacteriophase. Mutagenic property of EMS was also reported by Heslot et al., (1959). Bautz and Freese (1960) and Freese (1963) reported that EMS react with three of the four bases of DNA except thymine and causes more gene mutation than chromosomal break. This was subsequently attested by Kreig (1963) who reported that the action of EMS on base was in order of guanine > adenine > cytosine > thymine. Methyl group of EMS react with $\mathrm{N}-7$ position of guanine to form 7ethyl-guanine, thereby inducing both point mutation and chromosomal break.

Sodium azide (SA) is well known of heavy metal enzymes with influences on metabolism and respiration of living cell. The mutagenic effect of the SA is greatly depends on the $\mathrm{pH}$ of the treatment solution. SA is an inhibitor of the terminal segment of the electron transport chain. The physiological effect of SA is the inhibition of catalase, peroxidase and cytochrome oxidase, and effects in cell cycle and metabolism. SA was found to decrease the cellular level of catmodulin, which is calcium binding protein participating in signal transduction and cell division. SA is used for the first time as mutagene by Nillam et al., (1973) in barly. Different mutation breeding studies on groundnut involves seed treatment of a popular germplasm material in order to generate mutant genotype with additional desirable characteristics with different mutagens at various levels of concentrations. Present study involves genotype 'LGN-1'from a local seed market as base plant population utilized to evaluate mutagenic effects of two different chemical mutagens on groundnut seeds and characterize the desirable traits induced after mutation. Two different objectives of the present investigation are, Objectives-

To study the effect of germination percentage of groundnut at different concentration of sodium azide and ethyl methane sulphonate. 
To study the effect of growth parameters of groundnut at different concentration of Sodium Azide and Ethyl methane sulphonate (up to 60 days)

\section{Materials and Methods}

Experimental site: The experiment was conducted in Department of Plant Biotechnology in SDMVM's College of Agriculture Biotechnology, Georai Tanda, Aurangabad.

Collection of varieties: The groundnut variety LGN-1 was included as base population for present mutation breeding experiments. Truthful seeds were collected from the Oilseeds Research Station, Nanded Road, Latur

\section{Methodology}

Treatment of mutagens

\section{Ethyl methane sulfonate}

The groundnut seeds were pre-soaked in distilled water for 6 hours.

The EMS solution was prepared in distilled water.

Each concentration of EMS was prepared in $100 \mathrm{ml}$ of distilled water for 300 groundnut seeds, and a set of 300 seeds was kept in distilled water to serve as a control.

These soaked seeds treated with different concentration of EMS such as $0.2 \%, 0.4 \%$, $0.6 \%, 0.8 \%, 0.10 \% \& 0.12 \%$

After treatment, carefully remove the EMS solution and treated seeds were washed under running tap water to remove the traces of mutagen sticking to the seed coat (Gunasekaran et al., 2015)

\section{Sodium azide}

The sodium azide solution was prepared in $100 \mathrm{ml}$ distilled water for 300 seeds. The seeds were treated with six different concentrations viz. $0.2 \%, 0.4 \%, 0.6 \%, 0.8 \%$, $0.10 \%$ \& $0.12 \%$.

The treatments were given in capped vials with periodic shaking to maintain specific concentrations of the mutagen during treatment at room temperature.

A set of 300 seeds was kept in distilled water to serve as a control

After 24 hours of treatment, the seeds were thoroughly washed under running tap water to remove the residual mutagen sticking to the seed coat sowing of mutagen treated seeds (Mensah et al., 2007). In this experiment randomized block design (RBD) statistical design was used for analysis. In each mutagen six different treatments including one control treatment were utilized to induce differential mutations and evaluation of induced mutations. All treatments were replicated six times.

\section{Collection of data}

Initially 300 seeds were treated with different selected mutagen concentrations as per designated protocol. 100 treated seeds were sown in each treatment in three replications. Watering was done regularly as per recommendation for normal vegetative growth and development, Different agronomic observations was recorded at 30 days of interval from sowing date in following respect.

\section{Biometric observation}

Plants were observed on different growth parameters. 


\section{Germination (\%)}

The germination $\%$ was measured after seven days of interval.

\section{Number of leaves per plant}

The number of leaves proliferated was measure, after one month interval.

\section{Number of branches per plant}

The number of branches was count per plant, after branches formation.

\section{Average height of the plant}

The plant length was measured from base to the plantlet and the average length was express in centimeters.

\section{Plant survival (\%)}

Plant survival \% was measured after 45 DAS.

\section{Data analysis}

The agronomic data recorded at month interval after sowing was recorded for different plants from each treatment. Then averages were calculated from all plants from each treatment. Data obtained on various observations was subjected to analyze by "Analysis of variance" method.

\section{Results and Discussion}

Effect of SA and EMS on germination percentage of groundnut (LGN-1)

In the present study, it was found that there were reductions in the germination and survival percentage with increasing concentration of mutagen (sodium azide and ethyl methane sulphonate). The highest rate of germination was recorded in control treatment
(0.00\% of Sodium azide and ethyl methane sulphonate) of both the chemical such as $80.33 \%$ in sodium azide and $86.66 \%$ in ethyl methane sulphonate. Followed by the last treatment $(0.12 \%$ of sodium azide $)$ showed maximum amount of reduction and in ethyl methane sulphonate treatment T5 showed maximum amount reduction in seed germination showing that this dose proves to be lethal for both of the chemical under field condition (Table 1).

All the five treatment of sodium azide had an effect on germination percentage when compared with control treatment. In this treatment, the highest germination $(80.33 \%)$ was showed by the treatment $\mathrm{T}_{0}(0.00 \%$ of sodium azide) and the lowest germination (11.66 \% of sodium azide) was recorded by treatment $\mathrm{T}_{6}(0.12 \%$ of sodium azide $)$.

In this treatment of ethyl methane sulphonate, the maximum germination $(80.66 \%)$ was showed by the treatment $\mathrm{T}_{0}(0.00 \%$ of EMS $)$ and the lowest germination (59.33\%) was observed by treatment $\mathrm{T}_{5}(0.10 \%$ of EMS $)$

In this treatment of sodium azide, the higher number of leaves (20.53) was recorded by the treatment $\mathrm{T}_{0}(0.00 \%)$ followed to $\mathrm{T}_{1}(0.2 \%)$ which is significantly lower than T0 (18.66). Treatment $\mathrm{T}_{2}(0.4 \%)$ and $\mathrm{T}_{3}(0.6 \%)$ were significantly lower than Treatment $\mathrm{T}_{0}(0.0 \%)$ but which were at par with each other (18.36) and (17.93). $\mathrm{T}_{4}(0.8 \%)$ is superior over $\mathrm{T}_{5}$ $(0.10 \%)$ but significantly lower than $\mathrm{T}_{0}$ $(0.0 \%)$. The Treatment $\mathrm{T}_{6}(0.12 \%)$ was recorded lowest number of leaves.

In this treatment of ethyl methane sulphonate, the higher number of leaves (20.60) was recorded by the treatment $\mathrm{T}_{0}(0.0 \%)$ followed to $\mathrm{T}_{1}(0.2 \%)$ which were at par with each other (18.66). Treatment $\mathrm{T}_{2}(0.4 \%)$ and $\mathrm{T}_{3}$ $(0.6 \%)$ were significantly lower than Treatment $\mathrm{T}_{0}(0.0 \%)$ but which were at par 
with each other (18.66) and (17.33). Treatment $\mathrm{T}_{4}(0.8 \%)$ is superior over $\mathrm{T}_{5}$ $(0.10 \%)$ but significantly lower than $\mathrm{T}_{0}$ $(0.0 \%)$.

The treatment $\mathrm{T}_{6}(0.12 \%)$ was recorded lowest (15.60) number of leaves among the all treatment (Table 2).

The treatments of Sodium azide and Ethyl Methane sulphonate had an effect number of leaves when compared with control treatments. The results of present study indicated that in both SA and EMS is that when increase the dose concentration then decreases the number of leaves.
Effect of SA, EMS and treatments on number of branches per plant

In this treatment of sodium azide, the highest number of branches (5.33) was recorded by the treatment $\left.\mathrm{T}_{1} 0.2 \%\right)$ followed to $\mathrm{T}_{0}(0.0 \%)$ which were at par with each other (5.13). Treatment $\mathrm{T}_{2}(0.4 \%)$ and $\mathrm{T}_{3}(0.6 \%)$ were significantly lower than Treatment $\mathrm{T}_{0}(0.0 \%)$ but which were at par with each other (4.66) and $(4.50) . \mathrm{T}_{4}(0.8 \%)$ is superior over $\mathrm{T}_{5}$ $(0.10 \%)$ but significantly lower than $\mathrm{T}_{1}$ $(0.0 \%)$. The Treatment $\mathrm{T}_{6}(0.12 \%)$ showed lowest (3.33) number of branches among all the treatments.

Table.1 Effect of SA and EMS on germination percentage (\%) of groundnut (LGN-1)

\begin{tabular}{|c|c|c|}
\hline Treatment & S.A & EMS \\
\hline $\mathrm{T} 0(0.0 \%)$ & 80.33 & 86.66 \\
\hline $\mathrm{T}_{1}(0.2 \%)$ & 48.33 & 82.00 \\
\hline $\mathrm{T}_{2}(0.4 \%)$ & 44.00 & 81.00 \\
\hline $\mathrm{T}_{3}(0.6 \%)$ & 30.00 & 74.33 \\
\hline $\mathrm{T}_{4}(0.8 \%)$ & 21.00 & 67.33 \\
\hline $\mathrm{T}_{5}(0.10 \%)$ & 15.33 & 59.33 \\
\hline $\mathrm{T}_{6}(0.12 \%)$ & 11.66 & 67.00 \\
\hline
\end{tabular}

Table.2 Effect of SA and EMS treatments on number of leaves per plant

\begin{tabular}{|c|}
\hline Treatment \\
\hline $\mathrm{T} 0(0.0 \%)$ \\
\hline $\mathrm{T}_{1}(0.2 \%)$ \\
\hline $\mathrm{T}_{2}(0.4 \%)$ \\
\hline $\mathrm{T}_{3}(0.6 \%)$ \\
\hline $\mathrm{T}_{4}(0.8 \%)$ \\
\hline $\mathrm{T}_{5}(0.10 \%)$ \\
\hline $\mathrm{T}_{6}(0.12 \%)$ \\
\hline $\mathrm{SE} \pm$ \\
\hline $\mathrm{CD}$ \\
\hline
\end{tabular}

\begin{tabular}{|c|c|}
\hline S.A & EMS \\
\hline 20.53 & 20.60 \\
\hline 18.66 & 19.86 \\
\hline 18.36 & 18.66 \\
\hline 17.93 & 17.33 \\
\hline 17.60 & 17.26 \\
\hline 17.13 & 16.40 \\
\hline 13.33 & 15.60 \\
\hline $\mathbf{0 . 7 0}$ & $\mathbf{0 . 8 0}$ \\
\hline $\mathbf{1 . 4}$ & $\mathbf{1 . 5}$ \\
\hline
\end{tabular}


Effect of SA \& EMS \& treatments on No. of branches per plant

\begin{tabular}{|c|}
\hline Treatment \\
\hline $\mathrm{T} 0(0.0 \%)$ \\
\hline $\mathrm{T}_{1}(0.2 \%)$ \\
\hline $\mathrm{T}_{2}(0.4 \%)$ \\
\hline $\mathrm{T}_{3}(0.6 \%)$ \\
\hline $\mathrm{T}_{4}(0.8 \%)$ \\
\hline $\mathrm{T}_{5}(0.10 \%)$ \\
\hline $\mathrm{T}_{6}(0.12 \%)$ \\
\hline $\mathrm{SE} \pm$ \\
\hline $\mathrm{CD}$ \\
\hline
\end{tabular}

\begin{tabular}{|c|c|}
\hline S.A (cm) & EMS (cm) \\
\hline 12.86 & 12.53 \\
\hline 8.30 & 12.13 \\
\hline 9.53 & 11.00 \\
\hline 8.93 & 8.00 \\
\hline 9.13 & 8.00 \\
\hline 9.06 & 8.00 \\
\hline 7.30 & 6.33 \\
\hline $\mathbf{2 . 0}$ & $\mathbf{1 . 5 7}$ \\
\hline $\mathbf{2 . 5}$ & $\mathbf{2 . 3 3}$ \\
\hline
\end{tabular}
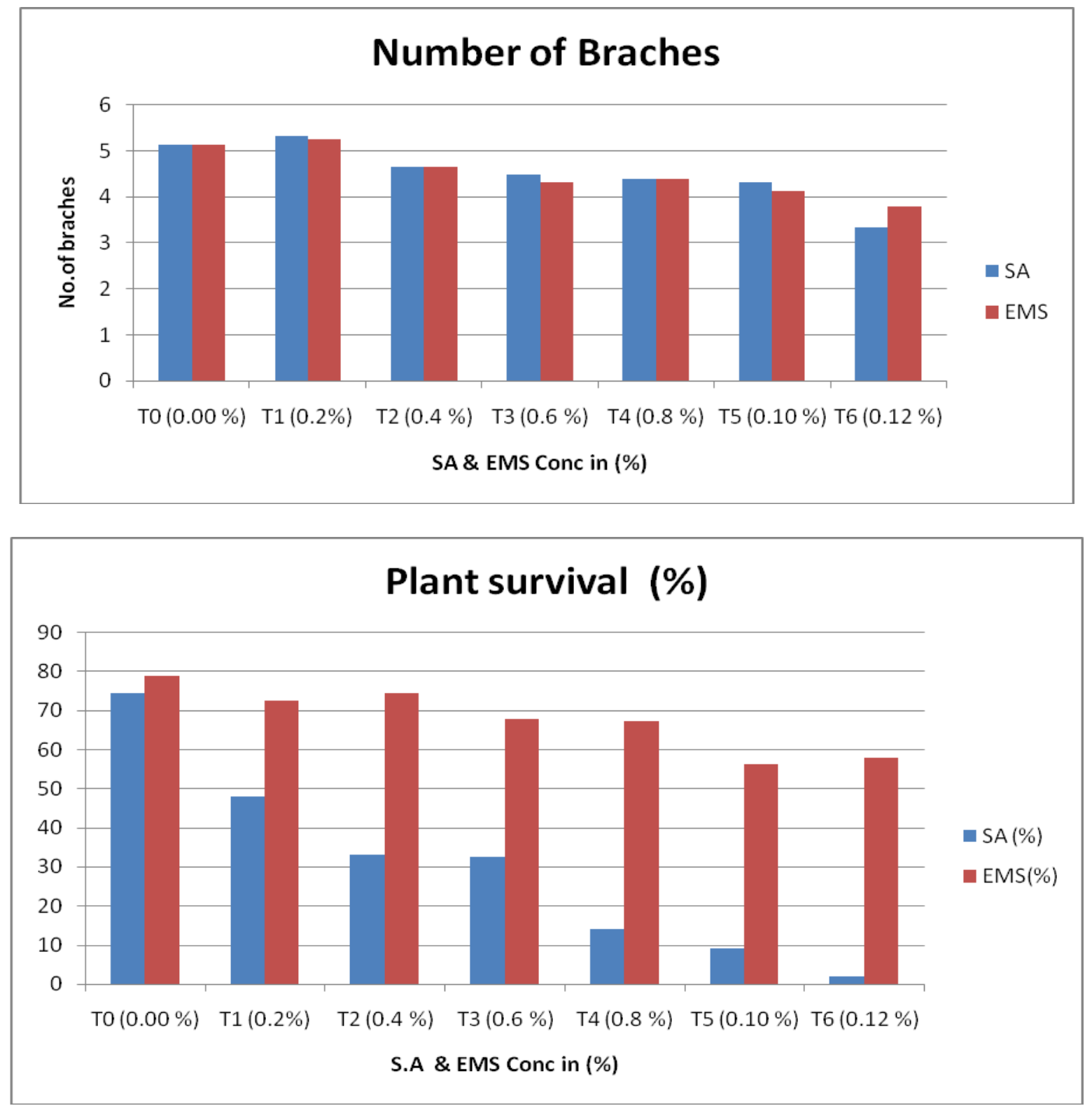
In this treatment of ethyl methane sulphonate, the highest number of branches (5.26) was recorded by the treatment $\mathrm{T}_{1} 0.2 \%$ ) followed to $\mathrm{T}_{0}(0.0 \%)$ which were at par with each other (5.13). Treatment $\mathrm{T}_{2}(0.4 \%)$ and $\mathrm{T}_{3}$ $(0.6 \%)$ were significantly lower than Treatment $\mathrm{T}_{0}(0.0 \%)$ but which were at par with each other (4.66) and (4.50). treatment $\mathrm{T}_{5}(0.10 \%)$ is superior over $\mathrm{T}_{4}(0.8 \%)$ but significantly lower than $\mathrm{T}_{1}(0.0 \%)$. The Treatment $\mathrm{T}_{6}(0.12 \%)$ showed lowest (3.80) number of branches among all the treatments.

In the present investigation, the maximum number of branches (5.33) in sodium azide and (5.26) in ethyl methane sulphonate was recorded in treatment $T_{1}$ of both chemical followed by (5.13) in $\mathrm{T}_{0}$ (control) treatment in both chemical.

\section{Effect of SA and EMS treatments on height of the plants}

In the present study, the highest plant height of sodium azide without treatment $(0.0 \%)$ was about $(12.86 \mathrm{~cm})$ followed by treatment $\mathrm{T}_{2}$ $(0.4 \%$ of sodium azide) recorded $(9.53 \mathrm{~cm})$ and in ethyl methane sulphonate the treatment $\mathrm{T}_{0}(0.0 \%)$ showed the maximum plant height $(12.53 \mathrm{~cm})$ followed by treatment $\mathrm{T}_{1}(0.2 \%)$ recorded (12.13) plant height.

\section{Effect of SA and EMS on plant survival (\%) of groundnut (LGN-1)}

In the treatment sodium azide, the highest number of plant $(74.66 \%)$ survived in the treatment $\mathrm{T}_{0}(0.0 \%$ of sodium azide $)$ and lowest number of plant (2\%) survived in treatment $\mathrm{T}_{6}(0.12 \%$ of sodium azide $)$ and In the treatment of ethyl methane sulphonate, the highest number of plant $(79 \%)$ survived in the treatment $\mathrm{T}_{0}(0.0 \%$ of ethyl methane sulphonate) and lowest number of plant $(56.33 \%)$ survived in treatment $\mathrm{T}_{5}(0.10 \%$ of ethyl methane sulphonate).The results of present study indicated that same type of work already observed in sodium azide treatments by Mensah et al., (2007), and also Gunasekaran et al., (2015) have worked on ethyl methane sulphonate.

The mutation resulted in the release of genetic variability in the mutagen treated plants of groundnut (LGN-1). It was observed that the increasing dose of sodium azide was showed adverse effect on germination percentage (\%) as well as morphological characters on groundnut the application of sodium azide at $\mathrm{T}_{1}(0.2 \%$ of sodium azide) showed similar results in growth parameters such as number of leaves (18.66), plant height $(8.30 \mathrm{~cm})$, number of branches (5.33) as compared with the control $(20.53,12.86 \mathrm{~cm}, \quad 5.13$ respectively) Similarly, ethyl methane sulphonate at $\mathrm{T}_{1}(0.2 \%$ of EMS $)$ showed similar results in growth parameters such as number of leaves (19.86), plant height $(12.13 \mathrm{~cm})$, number of branches $(5.26)$ as compared with the control (20.60,12.53 $\mathrm{cm}, 5.13$ respectively) Thus, it is concluded that sodium azide and ethyl methane sulphonate at $(0.2 \%$ of sodium azide and EMS) low concentration appear to be the better effective treatment for inducing variability as compare with other concentrations of sodium azide and ethyl methane sulphonate $(0.4 \%$ to $0.12 \%)$.

\section{References}

Ambreen Akhtar, Myk Ansari, Alka and Hisamuddin. 2012. Cytological effect of ethyl methane sulphonate and sodium azide in Linum usitatissimum L; Department of Botany, Aligarh Muslim University, Aligarh, 202002, U.P. India.

Fao Statistics, Food and Agriculture Organization, www.Fao.Org, (2014)

Gunasekaran, A., P. Pavadai, Studied on Induced Physical and Chemical Mutagenesis in Groundnut (Arachis 
hypogaea) International Letters Of Natural Sciences, (2015); 25-35

Kaveri Sb, Nadaf Hl. 2008. Mutation Breeding for Quantitative Characters in Groundnut (Arachis hypogaea L.), Crop Research, 35 (1\& 2): 91-94.

Kharade, M.R., S.V. Yamgar, A.R. Phadtare. Studied on effect of mutagenesis in groundnut to induce variability in seed quality parameters (Arachis hypogaea L.) IOSR Journal of Agriculture and Veterinary Science (IOSR-JAVS) Volume 8, Issue 7 Ver. Ii (July. 2015).

Maryam AH, Kasimu AA. 2016. Effect of combined doses of gamma ray and sodium azide (mutagenic agents) on the morphological traits of some varieties of okra (Abelmoschus esculentus). Afr. J. Agri. Res., 11(32): 2968-2973.

Mensah, J. K., and B. Obadoni. 2007. Effects of sodium azide on yield parameters of groundnut (Arachis hypogaea L.) African Journal of Biotechnology ,Vol. 6 (6), Pp. 668-671, 19 March 2007; Academic Journals.

Muniappan, V., S. Palanivel and S. Parvathi, Impact of ethyl methane sulphonate on M1 attributes of groundnut, Department of Botany, Government Arts College (Autonomous) Karur-639 005, Tamil Nadu, India (2016).

Odeje SC, Adamu AK, Muhammad H. Combined effects of gamma rays and sodium azide on yield components of selected varieties of guinea corn (Sorghum bicolor L). IOSR. J. Agri. Veterinary Sci, 2016; 9(5):15-20.

Pattee, H. E., C. T. Young, J. L. Pearson, J. A. Singleton', and F. G. Giesbrech P Storage and Moisture Effects on Peanut Composition and Roasted Flavor (1982).

Right Table, United States Department of Agriculture Research Service, National Nutrient Database for Standard Reference Release 28, (2016).

Sanjay Kumar, Singh DN and Srivatsava S. 1997. Combined Mutagenesis in Groundnut (Arachis hypogaea L.), Gau Research Journal, 23(1): 28-31.

Singh DN. 1998. Variability and dose effect of gamma rays in combined mutagenesis of groundnut. (Arachis hypogaea L.). Annals of Agricultural Research, 19 (1): 49-53.

Toker, C., Shyam S. Yadav and I. S. Solanki, Department of plant breeding, chaudhary charan Singh Haryana Agricultural University Hisar 125004, Haryana, India.

Zhu, M. Y., Pan, J., Wang, L., Gua, Q., and Huang, C. Mutation induced enhancement of al tolerance in barley cell lines. Methods Mol. Biol. 2003. 236:189-2.

\section{How to cite this article:}

Mayur V. Jadhav, Rahul K. Zote and Amol D. Sable. 2018. Studies on Induced Chemical Mutagenesis in Groundnut (Arachis hypogaea L.). Int.J.Curr.Microbiol.App.Sci. 7(10): 16621669. doi: https://doi.org/10.20546/ijcmas.2018.710.190 